\title{
PENGATURAN HUKUM BAGI PELAKU USAHA TERKAIT KEGIATAN PROMOSI YANG MERUGIKAN PENGGUNA JALAN
}

\author{
Oleh : \\ Ida Ayu Gede Sinta Surya Lestari* \\ Nyoman A. Martana** \\ Bagian Hukum Bisnis \\ Fakultas HukumUniversitas Udayana
}

\begin{abstract}
ABSTARK
Pelaku usaha tidak sepatutnya melakukan kegiatan promosi di jalan, dengan pola pemasaran memberikan brosur kepada setiap pengguna jalan khususnya pengendara kendaraan bermotor yang sedang melintas. Motif ekonomi mengakibatkan pelaku usaha menghalalkan segala cara agar hal tersebut tercapai, tanpa mempertimbangkan dampak yang ditimbulkan terhadap lingkungan sekitar, baik dalam hal ketertiban, keamanan, kebersihan, dan kenyamanan yang berkaitan dengan tanggung jawab sosial dan lingkungan perusahaan. Tujuan penulisan ini adalah untuk mengetahui pengaturan serta sanksi hukum terkait kegiatan promosi bagi pelaku usaha yang merugikan pengguna jalan. Metode penelitian yang digunakan dalam penulisan karya ilmiah ini adalah penelitian hukum normatif. Adapun kesimpulan dari penulisan ini adalah pengaturan dan sanksi hukum terkait kegiatan promosi bagi pelaku usaha yang merugikan pengguna jalan terdapat dalam peraturan perundang-undangan yaitu Undang 25 Tahun 2007 tentang Penanaman Modal, UndangUndang No. 40 Tahun 2007 tentang Perseroan Terbatas, Peraturan Pemerintah No. 47 Tahun 2012 tentang Tanggung Jawab Sosial dan Lingkungan Perseroan Terbatas dan secara khusus diatur dalam Peraturan Daerah Kota Denpasar No. 1 Tahun 2015 tentang Ketertiban Umum.
\end{abstract}

Kata Kunci: Promosi, Pelaku Usaha, Pengguna Jalan, Pengaturan.

*Mahasiswa Program Studi (S1) Ilmu Hukum Fakultas Hukum Universitas Udayana, Denpasar, Bali, e-mail: idaayusinta3@gmail.com.

**Dosen Fakultas Hukum Universitas Udayana, Denpasar, Bali, e-mail: nyomanamartana@gmail.com. 


\begin{abstract}
Business people should not carry out promotional activities on the road, with a marketing pattern providing brochures to every road user, especially motorists who are passing. Economic motives result in business actors justifying any means to achieve this, without considering the impact on the surrounding environment, both in terms of order, security, cleanliness and comfort related to corporate social and environmental responsibility. The purpose of this paper is to find out legal arrangements and sanctions related to promotional activities for business actors that harm road users. The research method used in writing scientific papers is normative legal research. The conclusions of this paper are that legal regulations and sanctions related to promotional activities for business actors that harm road users are contained in legislation, namely Law 25 of 2007 concerning Investment, Law No. 40 of 2007 concerning Limited Liability Companies, Government Regulation No. 47 of 2012 concerning Social and Environmental Responsibilities of Limited Liability Companies and specifically regulated in the Regional Regulation of Denpasar City No. 1 of 2015 concerning Public Order.
\end{abstract}

Keywords: Promotion, Business Actors, Road Users, Arrangements.

\title{
I. PENDAHULUAN
}

\subsection{Latar Belakang}

Persaingan usaha antar pelaku usaha semakin berkembang seiring banyaknya penemuan-penemuan baru di berbagai bidang usaha. Setiap pelaku usaha mempunyai motif ekonomi yaitu memperoleh keuntungan yang sebesar-besarnya yang menjadi penyebab pelaku usaha menghalalkan berbagai macam cara demi terwujudnya hal tersebut. Dengan persaingan usaha yang semakin berkembang mengakibatkan para pelaku usaha bersaing untuk memperkenalkan produk usahanya. Pelaku usaha mempunyai kewajiban untuk memberikan informasi ${ }^{2}$ mengenai produk yang diperdagangkan, salah satunya dilakukan dalam bentuk promosi.

${ }^{2}$ Celina Tri Siwi Kristiyani, 2011, Hukum Perlindungan Konsumen, Sinar Grafika, Jakarta, h. 44. 
Dalam hal ini, kegiatan promosi dilakukan di trotoar sampai pada badan jalan dengan pola pemasaran yaitu apabila ada kendaraan yang melintas terutama kendaraan bermotor maka sales promotion girl akan mendekati dan mengacungkan sebuah brosur kepada pengendara yang sedang melaju. Saat melakukan kegiatan promosinya, beberapa sales promotion girls juga menarinari sampai pada badan jalan sembari memberikan brosur kepada kendaraan yang melintas di jalan tersebut.

Pola pemasaran itu telah merugikan pengguna jalan khususnya keselamatan pengendara sepeda motor. Karena dapat mengalihkan perhatian dan menganggu konsentrasi para pengendara. Tidak sepatutnya jalan ataupun trotoar dijadikan tempat atau sasaran untuk kegiatan promosi hanya demi terwujudnya motif ekonomi, karena dapat menimbulkan dampak negatif. Tidak hanya keselamatan pengguna jalan namun juga berdampak pada ketertiban umum. Sepatutnya pelaku usaha tidak hanya berorientasi pada keuntungan saja, namun juga mempunyai kewajiban sosial maupun lingkungan sekitar dengan tujuan untuk tetap menciptakan hubungan usaha yang serasi, seimbang, dan sesuai dengan lingkungan, nilai, norma, dan budaya masyarakat setempat.

Maka dari itu, hukum menjadi suatu sarana yang ditujukan untuk mengubah tindakan masyarakat, dalam hal ini yaitu pelaku usaha. Pengaturan yang berisikan batasan-batasan dalam melakukan kegiatan apapun, termasuk promosi mempunyai peranan penting. Atas pertimbangan tersebut penulis mengangkat judul "Pengaturan Hukum Bagi Pelaku Usaha Terkait Promosi Yang Merugikan Pengguna Jalan". 


\subsection{Rumusan Masalah}

Adapun rumusan masalah yang dapat ditarik berdasarkan latar belakang tersebut adalah sebagai berikut:

1. Bagaimana pengaturan hukum bagi pelaku usaha terkait kegiatan promosi yang merugikan pengguna jalan?

2. Bagaimana sanksi hukum terkait kegiatan promosi bagi pelaku usaha yang merugikan pengguna jalan?

\subsection{Tujuan Penulisan}

Penulisan karya ilmiah ini bertujuan untuk mengetahui pengaturan hukum bagi pelaku usaha terkait kegiatan promosi yang merugikan pengguna jalan serta sanksi hukum terkait kegiatan promosi bagi pelaku usaha yang merugikan pengguna jalan.

\section{ISI MAKALAH \\ 2.1 Metode Penelitian \\ 2.1.1 Jenis Penelitian}

Metode penelitian yang digunakan dalam penulisan karya ilmiah ini adalah penelitian hukum normatif. Metode penelitian normatif merupakan penelitian kepustakaan yaitu penelitian terhadap data sekunder. ${ }^{3}$

\subsubsection{Jenis Pendekatan}

Penulisan karya ilmiah ini menggunakan pendekatan perundang-undangan. Pendekatan perundang-undangan yaitu pendekatan yang meneliti aturan-aturan yang berkaitan dengan isu hukum yang sedang terjadi.

3Peter Mahmud Marzuki, 2010, Penelitian Hukum, Kencana Prenada Media Group, Jakarta, h. 93. 


\subsubsection{Bahan Hukum}

Metode penelitian normatif merupakan metode yang digunakan di dalam penelitian hukum dengan meneliti bahan hukum primer dan bahan hukum sekunder. ${ }^{4}$ Berikut bahan hukum yang dipergunakan dalam karya ilmiah ini, yaitu :

a. Bahan hukum primer yang terdiri atas peraturan perundang-undangan yang berlaku yaitu Undang No. 40 Tahun 2007 tentang Perseroan Terbatas, Undang-Undang 25 Tahun 2007 tentang Penanaman Modal, Undang-Undang Nomor 22 Tahun 2009 tentang Lalu Lintas dan Angkutan Jalan, Peraturan Pemerintah Nomor 47 Tahun 2012 tentang Tanggung Jawab Sosial Dan Lingkungan Perseroan Terbatas serta Peraturan Daerah Kota Denpasar No. 1 Tahun 2015 tentang Ketertiban Umum.

b. Bahan hukum sekunder yang terdiri atas literatur, jurnal maupun karya tulis yang berkaitan dengan hukum perdata.

\subsection{Pengaturan Hukum Bagi Pelaku Usaha Terkait Promosi Suatu Produk Yang Merugikan Pengguna Jalan}

Pelaku usaha adalah setiap orang atau badan usaha yang berbentuk badan hukum maupun bukan badan hukum yang melakukan kegiatan dalam wilayah hukum Negara Republik Indonesia, baik sendiri maupun bersama-sama melalui perjanjian, menyelenggarakan kegiatan usaha dalam bidang ekonomi. Pelaku usaha dalam menjalankan kegiatan usahanya berasaskan demokrasi ekonomi dengan memperlihatkan keseimbangan antara kepentingan pelaku usaha dan kepentingan umum.

Setiap pelaku usaha mempunyai pihak-pihak yang membantu dalam menjalankan kegiatan usahanya seperti pelayan toko,

${ }^{4}$ Soerjono Soekanto dan Sri Mamudji, 2007, Penelitian Hukum Normatif: Suatu Tinjauan Singkat, PT RajaGrafindo Persada, Jakarta, h. 12. 
pekerja keliling, pengurus filial, pemegang prokurasi dan pimpinan perusahaan. Dari sekian jenis pihak yang membantu dalam perusahaan, yang sering dipergunakan adalah pelayan toko ${ }^{5}$ dan pekerja keliling.

Dalam kegiatan jual-beli yang dilakukan pelaku usaha tentu mempunyai suatu motif ekonomi. Motif ekonomi ini sekaligus menjadi tujuan dari pelaku usaha yaitu memperoleh keuntungan yang sebesar-besarnya. Dengan kata lain, pelaku usaha selalu berorientasi pada keuntungan. Karena keuntunganlah yang menjadi motivasinya dalam menjalankan suatu usaha. Hal tersebut yang menyebabkan pelaku usaha menghalalkan berbagai cara agar tercapainya motif ekonomi tersebut, seperti halnya yaitu promosi.

Promosi merupakan kegiatan penyebarluasan informasi suatu barang maupun jasa dengan tujuan menarik minat beli konsumen. Kegiatan promosi oleh pelaku usaha ini dilakukan di trotoar bahkan sampai pada badan jalan serta dilakukan sembari menari-nari, dengan pola pemasaran yaitu apabila ada kendaraan yang melintas terutama kendaraan bermotor maka pelayan toko dan pekerja keliling akan mendekati dan mengacungkan sebuah brosur kepada pengendara yang sedang melaju tersebut.

Promosi tersebut telah merugikan pengguna jalan karena dapat mengalihkan perhatian dan menganggu konsentrasi pengendara khususnys sepeda motor, yang dapat berakibat pada keselamatan pengendara itu sendiri. Sebagaimana UndangUndang No. 22 Tahun 2009 tentang Lalu Lintas dan Angkutan Jalan, menyatakan "Pengguna jalan adalah orang yang menggunakan jalan untuk berlalu lintas". Lalu lintas dan angkutan jalan yang mempunyai peran strategis dalam 
mendukung pembangunan dan integrasi nasional sebagai bagian dari upaya memajukan kesejahteraan masyarakat seperti amanat dalam Undang-Undang Dasar Negara Republik Indonesia Tahun 1945 justru mengakibatkan kerugian terhadap pengguna jalan dengan adanya pola pemasaran tersebut. ${ }^{6}$

Berdasarkan hal tersebut, diketahui bahwa antara tujuan yang hendak dicapai oleh pelaku usaha yaitu mendapatkan keuntungan yang sebesar-besarnya dengan implementasi di lapangan tidak seimbang, karena pola pemasaran yang dilakukan oleh pelaku usaha menimbulkan dampak negatif khususnya bagi pengguna jalan.

Kegiatan promosi oleh pelaku usaha yang merugikan pengguna jalan berkaitan dengan Tanggung Jawab Sosial dan Lingkungan, yang selanjutnya disebut TJSL. TJSL adalah tanggung jawab yang melekat pada setiap perusahaan untuk tetap menciptakan hubungan yang serasi, seimbang, dan sesuai dengan lingkungan, nilai, norma, dan budaya masyarakat setempat.

Kebijakan pemerintah dalam hal TJSL diatur dalam peraturan perundang-undangan yaitu Undang-Undang 25 Tahun 2007 tentang Penanaman Modal selanjutnya disebut dengan UUPM dan Undang-Undang No. 40 Tahun 2007 tentang Perseroan Terbatas yang selanjutnya disebut dengan UUPT.

Berdasarkan Pasal 15 huruf (b) UUPM mengatur bahwa "Setiap penanam modal berkewajiban untuk melaksanakan tanggung jawab sosial perusahaan." Dan, dalam Pasal 74 Ayat (1) UUPT mengatur bahwa "Perseroan yang menjalankan kegiatan usahanya di bidang dan/atau berkaitan dengan sumber daya alam wajib melaksanakan Tanggung Jawab Sosial dan Lingkungan."

6Dewa Arya Lanang Raharja, 2017,"Penyelenggara Jalan Sebagai Subyek Hukum Tindak Pidana", Jurnal Magister Hukum Udayana, Vol. 6, No. 1, h. 1, URL : https://ojs.unud.ac.id/index.php/jmhu/article/view/34572/20975 
Dengan adanya pengaturan tersebut menunjukkan bahwa TJSL merupakan suatu kewajiban bagi setiap perusahaan dalam menjalankan kegiatan usahanya yang bertujuan untuk tetap menciptakan hubungan perusahaan yang serasi, seimbang, dan sesuai dengan lingkungan, nilai, norma, dan budaya masyarakat.

Pengaturan hukum bagi pelaku usaha yang melakukan kegiatan promosi hingga merugikan pengguna jalan secara khusus diatur dalam Peraturan Daerah (Perda) Kota Denpasar No. 1 Tahun 2015 tentang Ketertiban Umum, yaitu Pasal 30 yang menyatakan bahwa "Dilarang menyodorkan brosur-brosur atau sejenisnya di jalan kepada setiap pengendara kendaraan bermotor, yang dapat menimbulkan gangguan ketertiban, keamanan, kebersihan, dan kenyamanan."

Dalam hal kegiatan usaha, terdapat pula pengaturan bagi pedagang kaki lima, yang selanjutnya disebut PKL. Yang dimaksud pedagang kaki lima adalah pedagang yang menjalankan kegiatan usaha dagang dan jasa non formal dalam jangka waktu tertentu dengan mempergunakan lahan fasilitas umum sebagai tempat usahanya, baik dengan menggunakan sarana atau perlengkapan yang mudah dipindah, dan/atau dibongkar pasang. Dalam Pasal 22 Ayat (1) Perda Kota Denpasar No. 1 Tahun 2015 yang menyatakan "Setiap PKL dilarang berjualan di jalan, trotoar, dan di bantaran sungai." Dan Ayat (2) yang menyatakan "Setiap PKL dilarang berjualan di jalur hijau, taman kota dan tempat umum lainnya kecuali diizinkan oleh Walikota."

Ketentuan pada Pasal 22 dan Pasal 30 tersebut diatas mempunyai keterkaitan yaitu adanya larangan untuk melakukan kegiatan yang bergerak di bidang kegiatan usaha dalam bentuk promosi maupun jual beli yang dapat menimbulkan kerugian di jalan 


\subsection{Sanksi Hukum Terkait Kegiatan Promosi Bagi Pelaku Usaha Yang Merugikan Pengguna Jalan}

Terkait dengan sanksi hukum akan mengacu pada beberapa peraturan perundang-undangan diantaranya UUPM, UUPT, Peraturan Pemerintah (PP) No. 47 Tahun 2012 tentang Tanggung Jawab Sosial dan Lingkungan Perseroan Terbatas, serta Perda Kota Denpasar No. 1 Tahun 2015 tentang Ketertiban Umum.

Dalam Pasal 74 ayat (3) UUPT menyatakan bahwa "Perseroan yang tidak melaksanakan kewajiban tersebut maka akan dikenakan sanksi sesuai dengan peraturan perundangundangan." Adapun peraturan pelaksana dari ketentuan Pasal 74 Ayat (3) UUPT terdapat pada PP No. 47 Tahun 2012 tentang Tanggung Jawab Sosial dan Lingkungan Perseroan Terbatas, khususnya Pasal 7 yang menyatakan "Perseroan sebagaimana dimaksud dalam Pasal 3 yang tidak melaksanakan tanggung jawab sosial dan lingkungan dikenai sanksi sesuai dengan ketentuan peraturan perundang-undangan."

Dengan memahami ketentuan pasal terkait TJSL yang tercantum dalam UUPT dan PP No. 47 Tahun 2012 maka dapat diketahui bahwa peraturan perundang-undangan tersebut tidak mengatur secara tegas sanksi terhadap perusahaan yang tidak melaksanakan TJSL. Maka dari itu terdapat kekaburan norma terhadap pemberian sanksi apabila terjadi suatu pelanggaran kewajiban TJSL.

Sedangkan, dalam Pasal 34 Ayat (1) UUPM menyatakan "Badan usaha atau usaha perseorangan sebagaimana dimaksud dalam Pasal 5 yang tidak memenuhi kewajiban sebagaimana ditentukan dalam Pasal 15 dapat dikenai sanksi administratif berupa: peringatan tertulis; pembatasan kegiatan usaha; pembekuan kegiatan usaha dan/atau fasilitas penanaman modal; 
atau pencabutan kegiatan usaha dan/atau fasilitas penanaman modal. Lalu, Pasal 34 Ayat (3) UUPM menyatakan "Selain dikenai sanksi administratif, badan usaha atau usaha perseorangan dapat dikenai sanksi lainnya sesuai dengan ketentuan peraturan perundang-undangan." Berdasarkan ketentuan pasal tersebut bahwasanya telah dinyatakan secara tegas mengenai sanksi bagi penanam modal yang tidak melaksanakan tanggung jawab sosial perusahaan.

Dalam hal ini, permasalahan yang terjadi yaitu di daerah Kota Denpasar maka pemerintah daerah sebagai penyelenggara pemerintahan daerah tidak terlepas dari tugas untuk membina ketentraman dan ketertiban masyarakat di daerahnya. Peraturan daerah harus sesuai dengan keadaan masyarakat di mana peraturan daerah tersebut diberlakukan. Sebagai penyelenggara pemerintahan daerah maka pemerintah daerah dituntut untuk memahami dukungan dan tuntutan yang berkembang dalam masyarakatnya. ${ }^{7}$

Sanksi hukum terkait kegiatan promosi oleh pelaku usaha yang menganggu pengguna jalan, secara khusus terdapat pada Pasal 57 Ayat (2) Perda Kota Denpasar No. 1 Tahun 2015 yang menyatakan bahwa: "Setiap orang yang melanggar ketentuan dalam Pasal 7 huruf a, Pasal 17, Pasal 28, Pasal 29, Pasal 30, Pasal 31 ayat (2), Pasal 37 ayat (1) huruf b dan huruf e Peraturan Daerah ini dikenakan denda paling banyak Rp.10.000.000 (sepuluh juta rupiah)." Dan, Pasal 58 Ayat (1) yang menyatakan bahwa "Setiap orang yang melanggar ketentuan dalam Pasal 9, Pasal 11, Pasal 16, Pasal 22, Pasal 23 ayat (4), Pasal 25, Pasal 26, Pasal 32, Pasal 35, Pasal 37 ayat (2), Pasal 38, dan Pasal 40 ayat

7I Wayan Suandi, 2008, "Pendekatan Sistem Pembentukkan Peraturan Daerah", Jurnal Kertha Patrika, Vol. 33 No. 1, h. 2, URL: https://ojs.unud.ac.id/index.php/kerthapatrika/article/view/3264 
(1) Peraturan Daerah ini diancam dengan pidana kurungan paling lama 3 (tiga) bulan atau denda paling banyak Rp.25.000.000 (dua puluh lima juta rupiah).

Terlepas dari pengaturan diatas, pihak pengusaha sepatutnya berdiskusi dan melakukan pendekatan-pendekatan dengan pihak-pihak yang ahli dibidangnya, dalam kasus ini yaitu perusahaan yang ada di Kota Denpasar dan beberapa tempat yang lain seharusnya sudah mengetahui apakah kegiatan usahanya tidak menimbulkan dampak negatif bagi pengguna jalan sampai ketertiban umum. Sehingga perusahaan dapat melakukan usaha preventif terhadap dampak negatif yang nantinya dapat menimbulkan kerugian untuk kedua belah pihak yakni antara pengusaha dengan pengguna jalan terkait dengan ketertiban umum. Sepatutnya kegiatan promosi yang dilakukan di tempat pejalan kaki (trotoar), diberikan batasan sampai mana pelayan toko maupun pekerja keliling bisa memberikan brosur sehingga tidak harus sampai masuk pada badan jalan.

Dengan mengkaji ketentuan-ketentuan pasal tersebut maka peran serta dari pemerintah daerah sangat diperlukan khususnya pemerintah daerah Kota Denpasar sejalan dengan pendapat G. Radbruch bahwa penegakan hukum memiliki tujuan yaitu kepastian, keadilan dan kemanfaatan. ${ }^{8}$

8Muhamad Erwin, 2013, Filsafat Hukum: Refleksi Kritis Terhadap Hukum, PT RajaGrafindo Persada, Jakarta, h. 123. 


\section{PENUTUP}

\subsection{Kesimpulan}

Adapun kesimpulan yang dapat ditarik dari pemaparan tersebut yaitu sebagai berikut:

1. Bahwa dampak yang ditimbulkan dari kegiatan promosi yang merugikan pengguna jalan berkaitan dengan tanggung jawab sosial dan lingkungan perusahaan. Pengaturan hukum bagi pelaku usaha terkait terkait hal tersebut terdapat pada 74 Ayat (1) UUPT, Pasal 15 huruf (b) UUPM, dan Pasal 7 PP No. 47 Tahun 2012 yang menyatakan bahwa tanggung jawab sosial dan lingkungan merupakan suatu kewajiban bagi setiap perusahaan dalam menjalankan kegiatan usahanya. Dan, secara khusus diatur dalam Pasal 30 Perda Kota Denpasar No. 1 Tahun 2015 tentang Ketertiban Umum, yaitu adanya larangan untuk menyodorkan brosur-brosur atau sejenisnya di jalan kepada setiap pengendara kendaraan bermotor, yang dapat menimbulkan gangguan ketertiban, keamanan, kebersihan, dan kenyamanan.

2. Terkait dengan sanksi hukum, terdapat pada Pasal 7 PP No. 47 Tahun 2012 yang merupakan peraturan pelaksana dari UUPT, namun tidak diatur secara tegas sanksi terhadap perusahaan yang tidak melaksanakan tanggung jawab sosial dan lingkungan. Kemudian, dalam Pasal 34 Ayat (3) UUPM telah diatur secara tegas mengenai sanksi yaitu adanya sanksi administratif bagi penanam modal yang tidak melaksanakan tanggung jawab sosial perusahaan. Dan, secara khusus diatur dalam Pasal 57 Ayat (2) Perda Kota Denpasar No. 1 Tahun 2015 dengan ancaman denda paling banyak Rp.10.000.000 (sepuluh juta rupiah). 


\subsection{Saran}

Berdasarkan kesimpulan tersebut di atas, maka disarankan sebagai berikut:

1. Dihimbau adanya kesadaran dari pelaku usaha untuk memahami aturan yang berlaku dalam menjalankan kegiatan usahanya. Dan tidak selalu berorientasi pada keuntungan saja, namun juga harus memperhatikan dampak yang akan terjadi dari kegiatan yang dilakukan.

2. Pengaturan sanksi dalam hal tanggung jawab sosial dan lingkungan yang terdapat dalam UUPT perlu ditegaskan lagi agar terwujudnya ketertiban, keamanan, kebersihan, dan kenyamanan dalam setiap kegiatan usaha. Serta pemerintah sepatutnya memperketat pengawasan terhadap prilaku pelaku usaha dalam menjalankan setiap kegiatan usahanya. 


\section{DAFTAR PUSTAKA}

\section{A. Buku}

Celina Tri Siwi Kristiyanti, 2011, Hukum Perlindungan Konsumen, Sinar Grafika, Jakarta.

Erwin, Muhamad, 2013, Filsafat Hukum: Refleksi Kritis terhadap Hukum, PT RajaGrafindo Persada, Jakarta.

Farida Hasyim, 2017, Hukum Dagang, Sinar Grafika, Jakarta.

Peter Mahmud Marzuki, 2010, Penelitian Hukum, Kencana Prenada Media Group, Jakarta.

Soerjono Soekanto dan Sri Mamudji. 2007. Penelitian Hukum Normatif: Suatu Tinjauan Singkat. PT RajaGrafindo Persada, Jakarta.

Udiana, I Made, 2018, Industrialisasi dan Tanggung Jawab Pengusaha Terhadap Tenaga Kerja Terlibat Hukum, Udayana University Press, Denpasar.

\section{B. Jurnal}

Arya Lanang Raharja, Dewa, 2017,"Penyelenggara Jalan Sebagai Subyek Hukum Tindak Pidana", Jurnal Magister Hukum Udayana, Vol. 6, No. 1, URL : https://ojs.unud.ac.id/index.php/jmhu/article/view/34572/ $\underline{20975}$

Suandi, I Wayan, 2008, "Pendekatan Sistem Pembentukkan Peraturan Daerah", Jurnal Kertha Patrika, Vol. 33 No. 1, URL: https://ojs.unud.ac.id/index.php/kerthapatrika/article/view $\lcm{13264}$

\section{Peraturan Perundang-undangan}

Undang-Undang 25 Tahun 2007 tentang Penanaman Modal (Lembaran Negara Republik Indonesia Tahun 2007 Nomor 67; Tambahan Lembaran Negara Republik Indonesia Nomor 4724).

Undang-Undang No. 40 Tahun 2007 tentang Perseroan Terbatas (Lembaran Negara Republik Indonesia Tahun 2007 Nomor 106; Tambahan Lembaran Negara Republik Indonesia Nomor 4756). 
Undang - Undang Nomor 22 Tahun 2009 tentang Lalu Lintas dan Angkutan Jalan (Lembaran Negara Republik Indonesia Tahun 2009 Nomor 96; Tambahan Lembaran Negara Republik Indonesia Nomor 5025).

Peraturan Pemerintah Nomor 47 Tahun 2012 tentang Tanggung Jawab Sosial Dan Lingkungan Perseroan Terbatas.

Peraturan Daerah Kota Denpasar No. 1 Tahun 2015 tentang Ketertiban Umum. 